\title{
Fluorine detoxification mechanisms of spent potlining incineration in response to calcium compounds
}

\author{
Guang Sun ${ }^{1}$, Gang Zhang ${ }^{1}$, Jingyong Liu ${ }^{1}$, Fatih Evrendilek ${ }^{1}$, and Musa Buyukada ${ }^{1}$ \\ ${ }^{1}$ Affiliation not available
}

May 13, 2020

\begin{abstract}
In this study, the detoxification and distribution mechanisms of fluorine during the spent potlining (SPL) incineration were characterized. $\mathrm{CaSiO} 3, \mathrm{CaO}, \mathrm{Ca}(\mathrm{OH}) 2$, and $\mathrm{CaCO} 3$-assissted $\mathrm{SPL}$ incineration detoxified $\mathrm{NaF}$ in the bottom ash yielding a conversion range of 54.24 to $99.45 \%$ relative to the individual SPL incineration. The fluorine leaching content of the bottom ash was estimated at $13.71 \mathrm{mg}$ ?L-1 after the SPL co-incineration with CaSiO3 (Ca:F=1.2:1). The two main mechanisms of the fluorine transformation were the substantial formations of $\mathrm{CaF}$, and $\mathrm{Ca} 4 \mathrm{Si} 2 \mathrm{O} 7 \mathrm{~F} 2$. The fluorine transformation efficiency was greater with $\mathrm{CaSiO} 3$ than $\mathrm{CaO}, \mathrm{Ca}(\mathrm{OH}) 2$, and $\mathrm{CaCO}$. Fluorine during the SPL co-incineration with $\mathrm{CaSiO} 3(\mathrm{Ca}: \mathrm{F}=1.2: 1)$ at $850{ }^{\circ} \mathrm{C}$ for $60 \mathrm{~min}$ was partitioned into $83.37,13.90$ and $2.72 \%$ in the bottom ash, fly ash, and flue gas, respectively. The transformation and detoxification mechanisms of fluorine provide new insights into controls over fluorine emission from the SPL incineration.
\end{abstract}

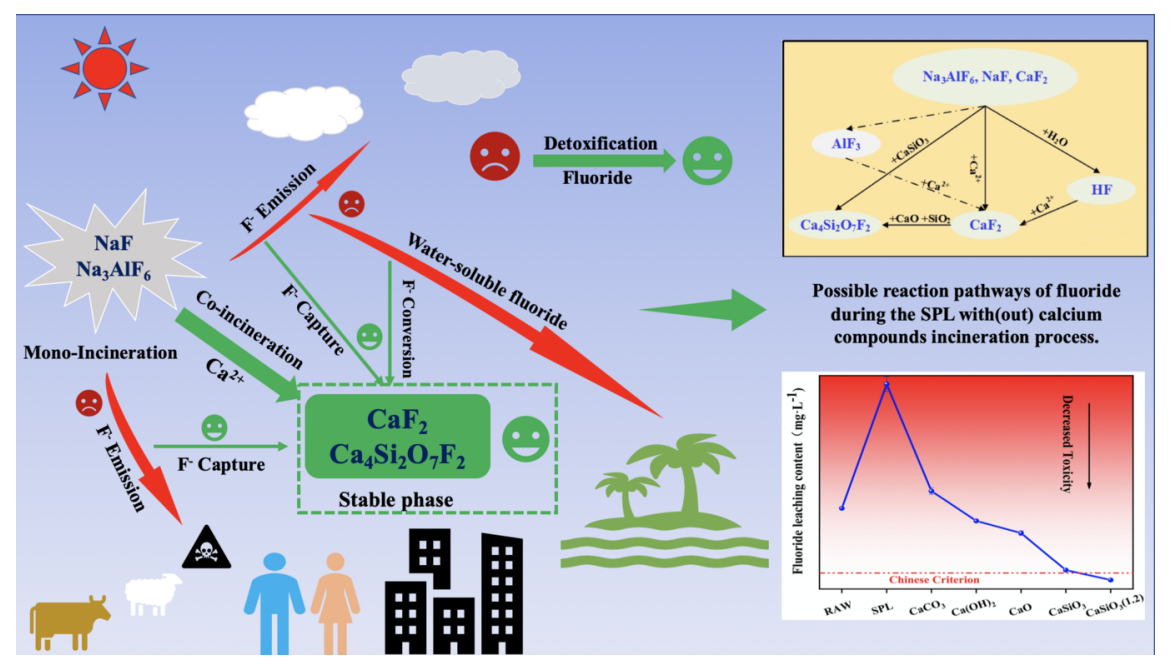

\section{Hosted file}

highlights-fe.docx available at https://authorea.com/users/321647/articles/450860-fluorinedetoxification-mechanisms-of-spent-potlining-incineration-in-response-to-calciumcompounds

\section{Hosted file}


manuscript-FE.docx available at https://authorea.com/users/321647/articles/450860-fluorinedetoxification-mechanisms-of-spent-potlining-incineration-in-response-to-calciumcompounds 